\title{
The prevalence of hyaline membrane disease and the value of shake test and lamellar body concentration in preterm infants
}

\author{
Dzulfikar DLH, MD; Ali Usman, MD; Melinda D Nataprawira, MD; Aris Primadi, MD
}

\begin{abstract}
Background The morbidity and mortality of hyaline membrane disease (HMD) are quite high due to delayed diagnosis and intervention. Commonly, HMD occurs in preterm infants with surfactant deficiency because of lung immaturity. Lung maturity test could be performed using biochemical, biophysical, and amniotic fluid turbidity test.

Objective To find out HMD prevalence and the value of shake test and lamellar body concentration in diagnosing HMD in preterm infants.

Methods This was a cross-sectional study carried out at Hasan Sadikin Hospital Bandung on preterm infants born during OctoberDecember 2001. The shake test was performed using gastric fluid and amniotic fluid while the lamellar body concentration was performed using amniotic fluid.

Results During the 3-month period, 571 infants were born, of 64 $(11.2 \%)$ preterm infants, only $41(64 \%)$ fulfilled the inclusion criteria; among those preterm infants, 14 (34\%) suffered from respiratory distress and 7 suffered from HMD (prevalence 17\%). All HMD cases occurred in infants less than 32 weeks for gestational age. In 7 preterm infants with HMD, the shake test of gastric fluid obtained by lavage showed negative results in 3 and +1 in 4 infants; while the shake test of amniotic fluid revealed negative result in 5 and +1 in 2 infants. Lamellar body concentration of amniotic fluid was $\leq 18,000 / \mathrm{ml}$ in all HMD infants. Among three infants less than 32 weeks for gestational age who did not suffer from HMD, +1 shake test of gastric fluid was found in 2 infants and +2 in 1 infant; while shake test of amniotic fluid showed negative result in 1 infant and +1 in 2; the lamellar body concentration of amniotic fluid was $\leq 18,000 / \mathrm{ml}$ in 2 infants and $>18,000 / \mathrm{ml}$ in 1 infant.

Conclusions We concluded that HMD occurred in $17 \%$ of preterm infants. The shake test of gastric and amniotic fluids revealed negative or +1 results whereas lamellar body concentration had value of less than or equal to $18,000 / \mathrm{mL}$. More extensive studies are warranted to assess the validity (sensitivity, specificity and predictive values) of these measurements [Paediatr Indones 2003;43:77-81].
\end{abstract}

Keywords: shake test, lamellar body, HMD, preterm infant
$\mathrm{P}$

erinatal mortality rate reported from several studies is still high and variable. ${ }^{1,2}$ Prematurity contributes for this perinatal mortality rate. ${ }^{3,4}$ Hyaline membrane disease (HMD) or respiratory distress syndrome type one is a complication that may occur in preterm infants. This disease is caused by surfactant deficiency due to lung immaturity. The prevalence of HMD is not similar among centers in the world and depends on the gestational age. ${ }^{5-8}$ Delayed diagnosis and intervention play an important role in HMD morbidity and mortality rates. To reduce the HMD mortality and morbidity rates and to determine optimal preterm infants follow up, it is necessary to evaluate HMD through lung maturity test. ${ }^{9,10}$ Shake test and lamellar body concentration could be used for early diagnosis of HMD but these procedures have not been studied yet.

The objective of this study was to find out the HMD prevalence in preterm infants and to evaluate the use of shake test and lamellar body concentration for early diagnosis of HMD.

From the Department of Child Health, Medical School, Padjadjaran University, Hasan Sadikin Hospital, Bandung.

Reprint requests to: Dzulfikar DLH, MD, Department of Child Health, Medical School, Padjadjaran University, Hasan Sadikin Hospital, Bandung, Indonesia. Tel. 62-21-2011282, Fax. 62-21-2032216. 


\section{Methods}

This was a descriptive-observational study with crosssectional design. Subjects were preterm infants born at Hasan Sadikin Hospital Bandung between October and December 2001. The inclusion criteria were gestational age of $28-<37$ weeks or of 196 to 258 days calculated from the recorded date of mother's last menstrual period and a signed parental informed consent. Subjects with amniotic fluid contaminated by maternal blood or meconium were excluded. History of pregnancy was taken from medical records. Maternal risk factors that influence lung maturity such as preeclampsia, placenta praevia and premature rupture of the membrane were observed for the occurrence of HMD. Shortly after birth, infant gastric fluid taken by lavage and amniotic fluid of the mothers was taken for the shake test and the assessment of lamellar body concentration. Afterwards, the infants were observed for any signs or symptoms of respiratory distress. Chest $\mathrm{x}$-ray was performed for every infant with respiratory distress to diagnose HMD.

\section{Results}

\section{The prevalence of HMD}

During the three-month study period, 571 infants were born at Hasan Sadikin Hospital Bandung and $64(11.2 \%)$ of them were preterm. Only 41 preterm infants fulfilled the inclusion criteria. Fourteen infants suffered from respiratory distress and 7 of them were diagnosed as having HMD. The prevalence of HMD was $17 \%$. All HMD babies were less than 32 weeks of gestational age. The characteristics of 41 preterm infants including sex, mode of delivery, maternal characteristics, and asphyxia are seen in Table 1.

\section{Shake test of gastric and amniotic fluid}

The interpretation of shake test ranged from negative to +4 , but of the 41 preterm infants no +4 result was noticed. (Figure 1 and 2)

Table 1. Characteristics of Subjects

\begin{tabular}{|c|c|c|c|c|}
\hline \multirow[t]{2}{*}{ No. } & \multirow[t]{2}{*}{ Characteristics } & \multicolumn{2}{|c|}{ HMD } & \multirow{2}{*}{$\begin{array}{l}\text { Total } \\
n=41\end{array}$} \\
\hline & & $\begin{array}{l}\text { Yes } \\
n=7\end{array}$ & $\begin{array}{l}\text { No } \\
n=34\end{array}$ & \\
\hline \multirow[t]{3}{*}{1} & Sex & & & \\
\hline & Male & 5 & 17 & 22 \\
\hline & Female & 2 & 17 & 19 \\
\hline \multirow[t]{4}{*}{2} & Mode of delivery & & & \\
\hline & Spontaneous & 2 & 15 & 17 \\
\hline & Cesarean section & 5 & 18 & 23 \\
\hline & Vacuum extraction & - & 1 & 1 \\
\hline \multirow[t]{3}{*}{3} & Asphyxia & & & \\
\hline & Yes & 4 & 10 & 14 \\
\hline & No & 3 & 24 & 27 \\
\hline \multirow[t]{3}{*}{4} & Twin & & & \\
\hline & Yes & - & 2 & 2 \\
\hline & No & 7 & 32 & 39 \\
\hline \multirow[t]{3}{*}{5} & Pre-eclampsia & & & \\
\hline & Yes & 2 & 6 & 8 \\
\hline & No & 5 & 28 & 33 \\
\hline \multirow[t]{3}{*}{6} & Placenta praevia & & & \\
\hline & Yes & 4 & 9 & 13 \\
\hline & No & 3 & 25 & 28 \\
\hline \multirow[t]{3}{*}{7} & $\begin{array}{l}\text { Premature rupture } \\
\text { of membrane }\end{array}$ & & & \\
\hline & Yes & - & 3 & 3 \\
\hline & No & 7 & 31 & 38 \\
\hline
\end{tabular}

78 • Paediatrica Indonesiana, Vol. 43 No. 5-6 • May - June 2003 


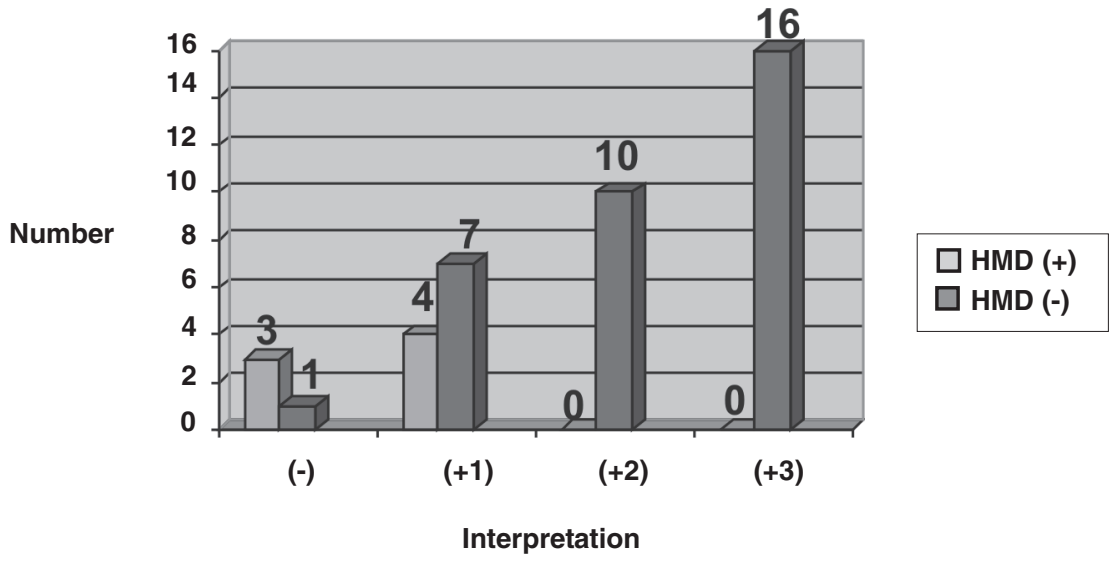

Figure 1. Shake test of gastric fluid

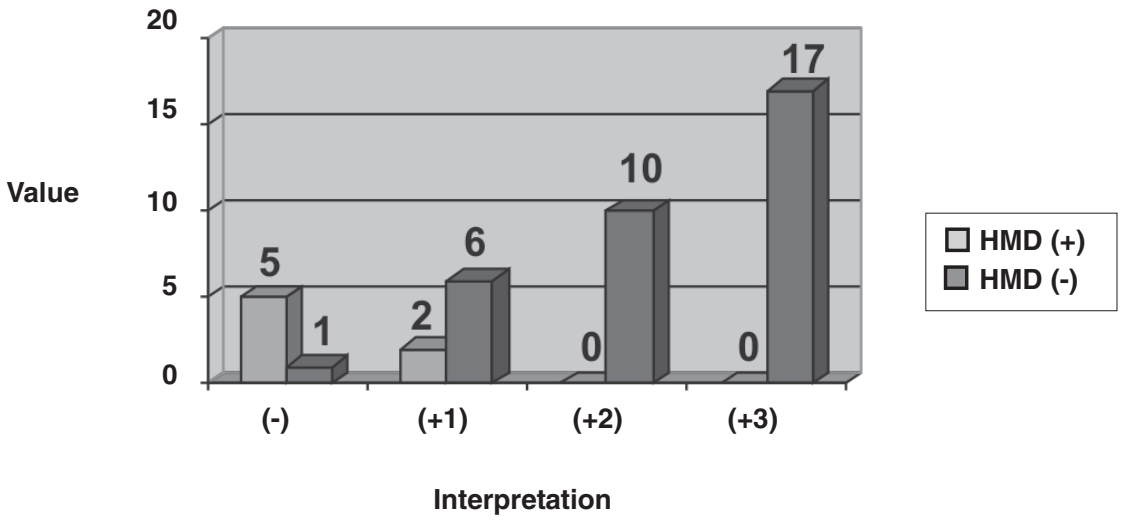

Figure 2. Shake test of amniotic fluid

\section{Lamellar body concentration}

The lamellar body concentration of 41 preterm infants is presented in Figure 3.

\section{Discussion}

The prevalence of hyaline membrane disease in preterm infants during this study period was $17 \%$ (7 out of 41 ). All infants with HMD had gestational age of less than 32 weeks. This result is in accordance with previous studies which revealed that the prevalence of HMD depends on gestational age. ${ }^{7,8,11}$ Preterm infants tend to experience HMD more often than the mature ones.

Infants who were born from mothers with preeclampsia had less HMD. Several studies revealed con- troversy in determining factors that affect lung maturity. Kulovich and Gluck (1979) showed that preeclampsia did not affect the acceleration of lung maturity; whereas Ferroni (1984) reported that preeclampsia though not depended on the severity and length of the disease could accelerate lung maturity significantly. ${ }^{9}$ Preterm infants born from mothers with placenta praevia had less HMD. All infants with premature rupture of the membranes in this study did not experience HMD. Male infants in this study suffered from HMD 2.2 times more than females. This rate was higher than the study conducted by Phelaw, Landau and Oliwski (1990) that revealed male infants suffered from HMD 1.7 times more than females. ${ }^{12}$ According to the mode of delivery, this study showed that infants born by cesarean section suffered from HMD more frequently than those by spontane- 


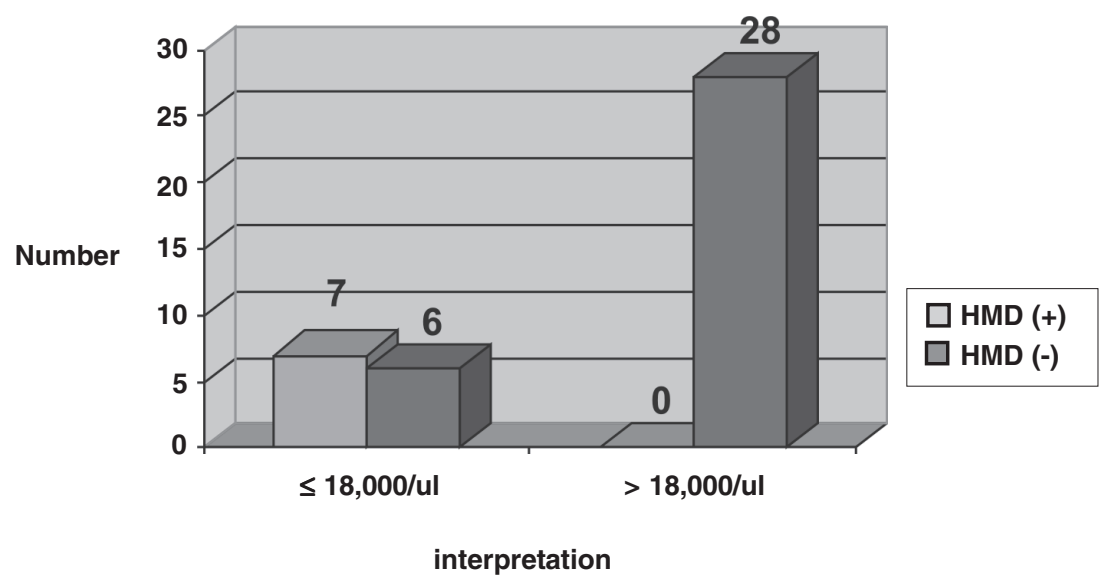

Figure 3. Lamellar body concentration

ous deliveries. Infants with perinatal asphyxia experienced HMD less than those without asphyxia.

All infants with HMD had negative or +1 gastric and amniotic fluid shake test and their gestational age was less than 32 weeks. This results supported previous studies which revealed that infants with a negative shake test had $60 \%$ probability of developing HMD and those with a +1 had a probability of $20 \% .{ }^{13}$ Preterm infants with HMD had lamellar body concentration of less than or equal to $18,000 / \mathrm{mL}$. This finding was lower than that of the studies conducted by Dubin (1989), Bowie (1991) and Dalence (1995) which showed lamellar body concentration of HMD infants of less than $30,000 / \mathrm{mL}$. This difference might be due to different methods and tools. ${ }^{14-16}$

We concluded that HMD occurred in $17 \%$ of preterm infants. The shake test of gastric and amniotic fluids revealed negative or +1 results whereas lamellar body concentration had value of less than or equal to $18,000 / \mathrm{mL}$. More extensive studies are warranted to assess the validity (sensitivity, specificity and predictive values) of these measurements.

\section{References}

1. Perera T, Lwin KM. Perinatal mortality and morbidity including low birthweight. WHO; 1984.

2. Cunningham FG. Diseases and injuries of the fetus and newborn: hyaline membrane disease. In: Cunningham FG, MacDonald PC, Gant NF, Leveno KJ, Gilstrap LC,
Hankins GDV, et al, editors. Williams Obstetrics. 20th ed. London: Appleton \& Lange; 1997. p. 967-71.

3. Smallwood R. Clinical Practice guidelines: care around preterm birth. Australia: NHMRC; 2000. p. 12-8.

4. Walker M, Hull A. Preterm labor and birth. In: Taeusch HW, Ballard RA, editors. Avery's diseases of the newborn. $7^{\text {th }}$ ed. Philadelphia: WB Saunders; 1998. p. 144-51.

5. Hansen T, Corbet A. Disorders of the transition: hyaline membrane disease. In: Taeusch HW, Ballard RA, editors. Avery's diseases of the newborn. $7^{\text {th }}$ ed. Philadelphia: WB Saunders; 1998. p. 602-13.

6. Bancalari E, Bidegain M. Respiratory disorders of the newborn: hyaline membrane disease. In: Taussig LM, Landau LI, Le Souef PN, Morgan WJ, Martinez FD, Sly PD, editors. Pediatric respiratory medicine. St. Louis: A Times Mirror; 1999. p. 464-71.

7. Gross I. Respiratory system: developmental consideration, respiratory distress syndrome. In: Mc Millan JA, DeAngelis CD, Feigin RD, Warshaw JB, editors. Oski's pediatrics principles and practice. $3^{\text {th }}$ ed. Philadelphia: Lippincott Williams \& Wilkins; 1999. p. 250-8.

8. Stoll BJ, Kliegman RM. The fetus and the neonatal infant. In: Behrman RE, Kliegman RM, Jenson HB, editors. Nelson textbook of pediatrics. $16^{\text {th }}$ ed. Philadelphia: WB Saunders; 2000. p. 451-3, 47785, 496-505.

9. Field NT, Gilbert WM. Current status of amniotic fluid test of fetal maturity. In: Pitkin RM, Scott JR, editors. Clinical obstetrics and gynecology. Lippincot: Raven publishers; 1997. p. 366-86. 
10. Gomella TL. Pulmonary disease: hyaline membrane disease (respiratory distress syndrome). In: Gomella TL, Cunningham MD, Eyal FG, Zenk KE, editors. A Lange clinical manual neonatology: management, procedures, on-call problems, disease, and drugs. $4^{\text {th }}$ ed. London: Appleton \& Lange; 1999. p. 503-6.

11. Rosenberg AA, Thilo EH. The newborn infant: hyaline membrane disease. In: Hay WW, Hayward AR, Levin MJ, Sondheimer JM, editors. Current pediatric diagnosis \& treatment. $14^{\text {th }}$ ed. London: Appleton \& Lange; 1999. p. 32-4.

12. Phelaw PD, Landau LI, Oliwski A. Neonatal respiratory disorders. In: Respiratory illness in children. $3^{\text {th }} \mathrm{ed}$. London: Blackwell Scientific Publ; 1990. p. 8-11.
13. Torday JS, Richardson DK. Tests for pulmonary surfactant. In: Cloherty JP, Stark AR, editors. Manual of neonatal care. $3^{\text {th }}$ ed. Boston: Little Brown; 1991. p. 195-9.

14. Dubin SB. Characterization of amniotic fluid lamellar body number density as the initial assessment in a fetal lung maturity test cascade. J Reprod Med 1995;260-6.

15. Bowie LJ, Shammo J, Dohnal JC, Farrel E, Vye MV. Lamellar body number density and the prediction of respiratory distress. Am J Clin Pathol 1991;95:781-6.

16. Dalence CR, Bowie LJ, Dohnal JC, Farrel EF, Neerhof MG. Amniotic fluid lamellar body count: a rapid and reliable fetal lung maturity test. Obstet Gynecol 1995;86:235-9. 